Articles

Studia Iuridica Lublinensia vol. XXVII, 3, 2018

DOI: $10.17951 /$ sil.2018.27.3.73-88

\title{
Marzena Myślińska
}

Maria Curie-Skłodowska University in Lublin

ORCiD: 0000-0002-1528-0952

marzena.myslinska@poczta.umcs.lublin.pl

\section{Mediation Functions Performed by Mediator during Mediation. Selected Problems}

\author{
Funkcje mediacyjne realizowane przez mediatora $w$ trakcie \\ mediacji. Wybrane zagadnienia
}

\section{SUMMARY}

The subject of this article is the analysis of the activity undertaken during mediation in the context of the characteristics of the mediation process and the normative conditions of the legal relationship and disputes resolved through this form of ADR. In order to implement the project, the content of the work will contain a list of functions performed by the mediator during mediation as 'the environment for performing the role' (which is not closed due to the dynamics of interaction in the negotiations). Their character and content determine the nature of the social and professional role of mediators in the Polish legal order, it also allows us to illustrate in detail the key issues for reflection on the professional role, including, for example, legal liability and conflict of roles. Mediation functions are diversified in terms of the frequency of their implementation depending, among other things, on the strategy of conducting mediation, the specificity of the dispute and the legal regulation of mediation. The discussion of the last of the indicated differentiating factors (i.e. the impact of universally binding law) will be reflected in the content of the paper.

Keywords: mediation; mediator; mediation function; decision-making process of mediation

\section{INTRODUCTION}

Mediation is one of forms of ADR consisting, simply speaking, in resolving disputes through discourse between the parties thereto, with the participation of an external third party, i.e. mediator. This form has become a regular element of the Polish legal order, and its popularity results not only from the benefits in comparison 
to the judicial type of dispute resolution ${ }^{1}$ but also as a result of normative solutions introduced into the legislation to encourage the use of mediation. In this regard, it is worth pointing to Article $187 \S 1$ Point 3 of the Code of Civil Procedure 2 , pursuant to which the content of a statement of claim must include information whether the parties have attempted mediation or other out-of-court resolution of the dispute, or provide the reasons for failing to do so.

The reasons for the expansion of the normative field for mediation within the Polish legal system, by introducing it to an increasing range of disputes, are rooted in both legal and social phenomena. The literature lists such legal phenomena as, in particular, the convergence of legal cultures, proceduralization of law, Europeanisation of law (especially the implementation of EU law), while the social ones include: differentiation of social cultures or change in the structure of disputes ${ }^{3}$ and the implementation of civil society principles ${ }^{4}$. The so-called judicial crisis and the related overburdening of courts are also crucial factors. Although assumptions of the decision-making process of mediation incorporated into the dispute resolution mechanism differ from those applied in judicial proceedings, mediation has become an auxiliary and supplementary form to support this process. This is evidenced not only by the impact of amicable settlements on issuing dispute-resolving judgements but also by the fact that mediation and other forms of ADR are covered by the term 'administration of justice' (provided that the court can review decisions concluding the dispute, taken as part of alternative forms $)^{5}$.

The ever-increasing importance of mediation entails the necessity to pay attention to the person of mediator as a mediation participant, and to the decision-making process taking place in mediation, especially in the context of the lack of detailed

1 In this respect, one may point out a shorter duration of mediation proceedings compared to a court trial, lower costs, and the possibility to directly influence the content of the decision concluding the dispute.

2 The Act of 17 November 1964 - Code of Civil Procedure (Journal of Laws, 2018, Item 155, consolidated text).

3 More on the topic in: L. Morawski, Główne problemy wspótczesnej filozofii prawa. Prawo w toku przemian, Warszawa 2003, p. 237, P. Kaczmarek, Dwa ujęcia proceduralizacji prawa, [in:] $Z$ zagadnień teorii i filozofii prawa. W poszukiwaniu podstaw prawa, red. A. Sulikowski, „Acta Universitatis Wratislaviensis" 2006, nr 2878, p. 215 ff.

4 In more detail: A. Korybski, Alternatywne rozwiazywanie sporów w USA. Studium teoretycznoprawne, Lublin 1993, p. 172.

5 See, e.g. L. Morawski, op. cit., p. 228. Certain normative acts of EU bodies also apply the broad sense of the notion 'administration of justice' including also alternative dispute resolution in the context of expanding access to justice; these include, for example: Green Paper on alternative dispute resolution in civil and commercial law of 10 April 2002, COM(2002)196. For more, see A. Zienkiewicz, Studium mediacji. Od teorii ku praktyce, Warszawa 2007, p. 224. Furthermore, it is important that this position is also taken by the Polish Constitutional Tribunal, e.g. in the judgement of 13 March 1996 (K 11/95, OTK 1996, No. 2, Item 9). More on the subject in: J. Oniszczuk, Konstytucja Rzeczypospolitej Polskiej w orzecznictwie Trybunału Konstytucyjnego, Kraków 2000, p. 737. 
regulations of its normative model, including the legal status, in the Polish legal system. The absence of these solutions results in the ambiguity in defining its role within the normative and cultural background of the Polish legal order. This issue is of paramount importance in the context of the discussion on professionalisation of the occupation of mediator, precision of the requirements imposed on mediators, professional liability, professional ethics or marketing activity due to competitiveness on the market of such services ${ }^{6}$. The context for these deliberations is the nature and specificity of the mediator's activities during mediation as a decision-making process vis-à-vis the characteristics of the institution of mediation itself and rules defining the mediator's position in mediation. A considerable portion of this article will tackle these issues.

\section{PRINCIPLES OF MEDIATION AND MEDIATOR'S POSITION}

Like the vast majority of other ADR forms, mediation is based on the principles of voluntary access, acceptability, confidentiality, autonomy of the conflict. These attributes determine the course and specificity of the decision-making process in mediation ${ }^{7}$. As to the first of them, participation in this form of ADR and reaching an agreement depends on the will of the parties. Acceptability boils down to the consent of the parties to the fact of participation in mediation (in the context of full awareness of the nature of this ADR form and the approval of participation in it), the person of mediator, and acceptance of individual options of the agreement and the final content of the settlement. Confidentiality involves the obligation to keep in secret the information disclosed by the parties during mediation (however, the confidentiality obligation is not absolute). Autonomy of the conflict allows the parties to the dispute to exercise their full discretion, because not only do they decide to submit the dispute to this form of ADR and set detailed rules for mediation, but also agree upon and determine the content of the settlement. These principles of mediation (including, in particular, autonomy of the conflict) determine the 'secondary' role of mediator in relation to the parties to the dispute, in contrast to arbitrariness and the decision-making authority granted to judges ${ }^{8}$.

6 For a detailed analysis of mediator's liability towards: parties to the mediation (contractual liability), mediator unions (professional association member liability), and penal liability in the perspective of the Polish legal system, see M. Myślińska, Mediator w polskim porzadku prawnym, Warszawa 2018, pp. 153-266.

7 More on the decision-making process in mediation as compared with court trial may be found in: eadem, The Processes of Application of Law and the Decision Making in Mediation Process, „Studia Iuridica Lublinensia” 2015, nr 2, DOI: http://dx.doi.org/10.17951/sil.2015.24.2.115, pp. 115-130.

${ }^{8}$ Ibidem, pp. 117-123. 
Mediation is a communication process whereby the parties to the dispute seek an agreement (settlement) with the assistance of a third party, i.e. the mediator. Thus, the process is characterized by its discursive nature, dynamic interaction between the parties, procedural rules based on both legal and non-legal norms. The features that determine the mediator's position during mediation are impartiality, neutrality, independence and selflessness. The first of these is related to the obligation to maintain an objective attitude towards the parties to mediation ${ }^{9}$. Therefore, the mediator may not support the interests of any party to the dispute, including manifesting his or her support or disapproval with regard to the position taken by either of them. Impartiality entails ensuring the balance between the parties during mediation at each stage thereof (hence the principle of balance between the parties proposed by some scholars).

Another rule to determine the mediator's position in mediation - independence - is related to the obligation to play one's role in mediation in a manner aimed at avoiding situations that may lead to a conflict of interest ${ }^{10}$. A conflict may be considered on two levels: either as a conflict of interest taking place in the mediator's relationship with the parties to mediation or as a conflict of various roles played by the mediator at the same time. The first of these levels can be analysed, for example, in the context of family, social or professional connections between the mediator and a party to the mediation, while the second one can be analysed for the event of parallel performance of the roles, the circumstances or nature of which are in conflict with the role of mediator. In the latter case, one can mention the combination of the roles of mediator and lawyer, which may seem problematic, as the implementation of the role of a mediator in mediation differs from that of a lawyer during court trial ${ }^{11}$.

The neutrality of the mediator is reflected in his or her attitude to the dispute and subject thereof ${ }^{12}$. An external third party may not make any suggestions regarding the content of the settlement, in particular by preferring specific options of the agreement, especially where they are aimed at pursuing that third party's private interest ${ }^{13}$. The last of the rules defining the mediator's in mediation - selflessness - is manifested in the prohibition on making conditional the quality of the performed activities upon remuneration for conducting mediation or the promise of extra remuneration from the parties/a party to the dispute in the context of a specific content of the settlement.

9 More on the topic of mediator's impartiality, see: R. Morek, Mediacja i arbitraż (art. $183^{{ }^{-}}$ $183^{15}, 1154-1217$ KPC). Komentarz, Warszawa 2006, pp. 56-58.

10 See ibidem, p. 57.

11 More on the conflict between the roles of mediator and lawyer: M. Myślińska, Mediator w polskim porzadku..., pp. 331-341.

12 More on the topic in: P. Waszkiewicz, Zasady mediacji, [in:] Mediacje. Teoria i praktyka, red. E. Gmurzyńska, R. Morek, Warszawa 2009, p. 97.

13 In more detail: G. Skrzypczak, Prawnik a sposoby rozwiązywania sporów. Prawnik wobec sytuacji konfliktowych, „Monitor Prawniczy” 2004, nr 4, p. 198. 
Normative solutions that make up the normative model of the mediator's role in the Polish legal order indicate guarantees of compliance with the rules (most notably impartiality). The mediator is obliged to notify the parties to the mediation about each case that demonstrates the biased character of mediator's behaviour, including the conflict-generating situation associated with combining the mediator's role with another social role - this duty is vested in the mediator regardless of the stage of mediation proceedings. This question is directly referred to in Article $183^{3}$ $\S 2$ of the Code of Civil Procedure and Article 96g $\S 1$ of the Code of Administrative Procedure ${ }^{14}$, which requires the mediator to inform the mediation parties about circumstances that may raise doubts as to impartiality. The consequence of this mediator's action should be refusal to conduct the mediation (Article 96g $\S 2$ of the Code of Administrative Procedure).

\section{MEDIATION FUNCTIONS}

Another of the issues which need to be explained in the context discussed herein covers functions performed by the mediator during mediation, by which I understand a set of activities of a similar nature, aimed at achieving a specific goal of the mediation. All the functions performed by the mediator during mediation is the most important element of the profession, deciding about the nature of the professional role. The necessity to achieve multi-faceted mediation objectives ${ }^{15}$ involves undertaking a series of interdisciplinary activities to help the mediation parties effectively close the dispute between them. The catalogue of mediation functions discussed in this part of the article is not a full list, as it contains those that are 'typical' and at the same time universal enough to refer them to each of the types of disputes regulated by a given branch of law. Of course, the 'intensity' of exercising any particular function may differ depending on the nature of a given dispute (whether in civil, criminal, or administrative disputes, etc.), and this issue will be briefly outlined in the further part of discussion.

As regards examples of mediation functions carried out by the mediator during mediation, one should start with those that aim to tackle psychological aspects of mediation related to eliminating negative emotions of the parties towards each other and the dispute itself, and the process of "self-cognition, self-improvement and internal moral growth of the parties"16. The first of these is the identification function, the

14 The Act of 14 June 1960 - Code of Administrative Procedure (Journal of Laws, 2017, Item 1257, consolidated text).

15 More on mediation goals, see A. Zienkiewicz, Specyfika dyskursu integracyjnego, [in:]

J. Bralczyk, Wymowa prawnicza, Warszawa 2014, pp. 193-194.

16 More on these processes in: idem, Studium mediacji..., p. 165. 
essence of which is to identify interests of the mediation parties (in their substantive, procedural, and psychological aspects), and their scope, as well as contradictions between the norms and values, constituting the structural basis of conflict ${ }^{17}$. The function of neutralising emotions of the parties during all stages of mediation correspond to the catalysing function ${ }^{18}$. It is the mediator's responsibility to contribute to reduce the conflict between the parties, including by building a positive psychological relationship between the parties to the dispute ${ }^{19}$. The external entity builds an atmosphere of cooperation and trust, creates an emotionally neutral space to promote rational discussion and emotional transformation of the parties. The mediator's task is to deal with manifestations of emotions (behavioural, cognitive, and physiological ${ }^{20}$, which results in that function being transformed into a therapeutic function.

The next functions discussed here (the informative, expert, educational and consultancy functions) are generally aimed at equipping the parties to the dispute with a specific knowledge base allowing them to resolve the dispute by mediation on their own. The first of them boil down to giving the parties the knowledge on how the dispute is to be resolved through mediation, on the role and function performed by the mediator (characterised by neutrality, impartiality, selflessness and independence), procedural framework of mediation (in particular, voluntary access and confidentiality), mediation strategies applicable for the dispute, legal effects of the mediation settlement and feasibility of the options put forward by the parties, as well as the benefits and advantages of resolving the dispute in that way ${ }^{21}$. In performing these tasks, the mediator teaches the parties to the dispute how to independently shape the social relationship, and also points to the ways of resolving conflicts in the future (thus the function transforms into the educational function, and where it involves specialist knowledge in the field covered by the dispute - the expert function).

Among these functions, it is worth noting the advisory function, which can be considered debatable in the perspective of the rules determining the mediator's position in mediation (neutrality, impartiality and independence) and the rule of conflict. Therefore, it seems doubtful for the mediator to perform this function, especially if it took the form of support of only one of the parties to the mediation or imposing options of the agreement, or its comprehensive content, on the parties. The mediator's actions to push towards quick settlement, or firmly suggest a given option of the agreement should be considered as improper performance of duties,

17 In more detail: Ch. Moore, Mediacje. Praktyczne strategie rozwiazywania konfliktów, Warszawa 2009 , p. 74 .

18 More on behavioural, psychological and cognitive aspects of emotions cf. ibidem, pp. $175-179$.

19 More on psychological techniques that allow dealing with negative emotions in the parties during mediation: G. Nordhelle, Mediacja. Sztuka rozwiazywania konfliktów, Gdańsk 2010, pp. 248-257.

20 In more detail: Ch. Moore, op. cit., pp. 179-180.

${ }^{21}$ In more detail: ibidem, pp. 104-105. 
which are contrary to the idea of mediation and reconciliation between the parties by way of a mutually acceptable agreement ${ }^{22}$. Thus, performance of this function requires that the mediator is restrained in formulating opinions on the parties' positions or settlement options put forward by them while keeping an objective attitude towards the parties of mediation, a sense of balance and awareness of the decision-making position of the parties to the dispute.

Then it is worth paying attention to those of the mediator's functions which are related to the organisation of the mediation process, including the course of it. The first function that is crucial here is the procedural function, involving, necessary to ensure procedural fairness of mediation proceedings ${ }^{23}$. It is manifested in ensuring that the basic principles affecting the mediation procedure, i.e. the principles of voluntary access, conflict autonomy, acceptability and confidentiality, are adhered to. In addition, due to the informal nature of mediation, the mediator must ensure compliance with the detailed rules of mediation, which were agreed with the parties at the outset of interaction (such as the order of participants taking the floor). By performing activities typical for the function, the mediator plays, to a certain extent, a control role over the course of mediation, manages various stages of mediation proceedings, which leads, inter alia, to maintaining the equal position of both parties to the dispute.

The sphere of mediator's activity being discussed is linked with the organisational and stabilisation functions, whereby the mediator organises mediation in temporal, technical and spatial terms, and also takes care of the balance between the parties to the dispute during mediation. Where there is such an option available, the mediator selects an appropriate place to hold the mediation, which ensures the actual separation of parties and enabling a separate meeting with each of them. The mediator ensures the neutral character of the space, enabling free and uninterrupted communication, which is devoid of elements that may suggest an advantage or increased influence of one of the parties on the other. Furthermore, the mediator's role is to provide comfortable communication conditions (including silence allowing the parties to control their emotions and calm down), offer refreshments, etc. ${ }^{24}$ The balance between the parties ensured owing to the stabilisation function is a precondition for reaching an agreement acceptable to all parties. Thus, the mediator supports the weaker party, while restraining the excessive expansiveness of the stronger party, takes care of the emotional and communication balance between the parties and mutual understanding of the messages addressed to each other.

22 Cf. M. Tabernacka, Negocjacje i mediacje w sferze publicznej, Warszawa 2009, p. 34.

23 More on procedural fairness of metiation proceedings in: A. Zienkiewicz, Mediacja jako forma wymiaru sprawiedliwości, „ADR. Arbitraż i Mediacja” 2013, nr 4(24), pp. 107-109.

${ }^{24}$ See A. Cybulko, A. Siedlecka-Andrychowicz, Mediator: role, umiejętności, osobowość, [in:] Mediacje. Teoria ..., p. 170. 
As mentioned above, mediation is a communication process, and its main element is a discourse between the parties, thus the communicative function is the paramount function of those performed by the mediator during the mediation decision-making process. Basically, it involves the activity of moderating communication between the parties ${ }^{25}$. The mediator assists in and holds negotiations between the parties so as to help them communicate with each other in order to maximise the chances of reaching a settlement ${ }^{26}$. Activities to be taken by the mediator performing that function include in detail the following: assistance to the parties in defining the issues of contention and their articulating ${ }^{27}$, managing communication so as to prevent any possible escalation of the conflict, encouraging both parties to mutually understand messages addressed to each other.

To conclude the exemplification of mediation functions performed by the mediator during mediation, it is worth noting the somewhat subjective character of the authority function. Its essential element is building the mediator's credibility $v i s-\grave{a}$-vis the parties to the dispute and the social environment. The purpose of this credibility is to establish "a reason to expect that the mediator and mediation procedure will help them effectively resolve contentious issues" ${ }^{28}$. Irrespective of aspects of mediator's credibility (personal, institutional and procedural), this function requires keeping an attitude that reflects the idea of mediation (impartiality, independence, neutrality, selffessness), maintaining a proper reputation (attitude in one's private life) as well as skills and qualifications to conduct mediation aimed at achieving its multifaceted goals. The mediator's authority exercised in many aspects of credibility (e.g. personal, substantive) translates into the assessment by the parties whether it is reasonable to refer the case to mediation, increases their involvement in cooperation during negotiations, and consequently - affects the increase in the sense of ownership of the process of reaching the agreement.

\section{MEDIATION FUNCTIONS IN VIEW OF THE POLISH LEGAL SYSTEM}

The applicable law and regulation of particular types of mediation in the Polish legal system differently determine the content of the mediator's activities. Thus, mediation functions carried out by the mediator under particular types of mediation (distinguished according to the type of dispute under a given legal relationship) vary in terms of intensity (frequency). First of all, mediation in civil law should be men-

\footnotetext{
${ }^{25}$ Cf. Ch. Moore, op. cit., pp. 103-104.

26 See A. Cybulko, A. Siedlecka-Andrychowicz, op. cit., p. 168.

27 In more detail: Ch. Moore, op. cit., p. 191.

28 Ibidem, p. 101.
} 
tioned, as this branch of law constitutes a natural environment for $\mathrm{ADR}^{29}$. It covers subjective disputes typical for private law, which are characteristic for a combination of individual claims and circumstances ${ }^{30}$. The features of civil law which define the mediator's role and at the same time meet the principles of mediation are autonomy of the will of the parties, freedom of contract, equality of subjects of legal relations, and autonomous shaping of social relations (including legal relationships) $)^{31}$. The principles of voluntary access, autonomy of conflict, acceptability of mediation are fulfilled in an undisrupted manner within the area of these features. The independence of civil law entities in shaping their mutual relations generates perfect conditions for the discursive shaping of the content of the legal relationship.

The legal regulation of mediation in civil matters ${ }^{32}$, contained in the content of Articles $183^{1}-183^{15}$ of the Code of Civil Procedure governs in detail the tasks of a mediator conducting mediation in civil matters, in addition to referring to the principles that determine the nature of this form of dispute resolution and the position of a mediator (voluntariness, confidentiality, impartiality Thus, the legislature points to mediation functions to a very limited extent. Given this general nature of the regulation, there is no doubt that mediators will perform functions of a procedural nature, aimed at arranging the conditions for cooperative resolution of the dispute (that is the procedural, organisational and stabilising functions) - these functions stem in particular from Articles $183^{11}$ and $183^{13}$ of the Code of Civil Procedure ${ }^{33}$. Also, due to the content of Article $183^{8}$ of the Code of Civil Procedure which gives the mediator a prerogative to hold (once the parties are summoned by the chairperson) an information session on amicable dispute resolution - the information function becomes more important. In addition, attention should be paid to the content of Article $183^{3 \mathrm{a}}$ of the Code of Civil Procedure, which provides for the implementation of the advisory function exercised by an external third party, by allowing the mediator, upon a joint request of the parties, to propose the parties the content of the agreement $t^{34}$.

${ }^{29}$ In more detail: R. Morek, op. cit., p. 35.

30 See Z. Kmieciak, Mediacja w polskim prawie administracyjnym, [in:] Mediacja w prawie administracyjnym, red. H. Machińska, Warszawa 2007, p. 38.

31 Cf. R. Morek, op. cit., p. 47.

32 According to Article 1 of the Code of Civil Procedure: "The Code of Civil Procedure governs court proceedings in matters relating to civil, family and guardianship and labour law, as well as in matters of social security and other matters to which the provisions of this Code apply by virtue of specific legislation (civil matters)".

33 The first of these provisions requires the mediator to set the date and place of the mediation meeting, unless the parties have expressed their will to undertake the mediation without such a meeting, while the second one lays down the obligation to draw up a report on the mediation carried out.

34 Therefore, the mention on submitting such a request by the parties should be recorded in the mediation report drawn up by the mediator, or form an attachment thereto (provided that the parties have decided to prepare the request in writing). 
The specification of intensity of implementation of particular mediation functions in family, economic and labour disputes requires, as there is no detailed normative solutions in this respect, referring to the specificity of these legal relations. Strong emotions and increased (from the perspective of the party) emphasis on continuing relations in the future, so characteristic of family relations, strengthens, as compared with other types of civil disputes ${ }^{35}$, the intensity of functions of psychological nature, namely the catalytic, stabilisation and identification functions ${ }^{36}$. As regards to business matters, however, the professional nature of the parties to this type of disputes entails the intensity of the information, advisory and expert functions, especially in the context of the obligation for the mediator to have specialist knowledge in the field covered by the specific dispute. Individual employment relations as "the relations of subordinated labour provided to the employer on a voluntary basis, personally by the employee for a consideration, as well as other legal relationships intrinsically connected with labour relations" ${ }^{\prime 37}$, are characterised by the hierarchical subordination of the employee. The employer strives to increase the efficiency of work, while the employee strives to earn benefits in relation to the duties performed by him $^{38}$. Therefore, it is important to increase the intensity of the stabilisation function, aimed at maintaining the balance between the parties.

The exercise of mediation functions in criminal disputes is included in the implementation of the idea of restorative justice ${ }^{39}$, manifested in an attempt to remedy the damage caused, as well as in restitution of violated social ties ${ }^{40}$. Thus, the mediator proposes the parties to a dispute caused by a prohibited act (the injured party and the perpetrator) to attempt to reach an amicable solution, the idea of which is to forgive the perpetrator and to rectify the damage and apologise the injured party. Analysis of generally applicable legislation on mediation in criminal matters (i.e. Article 23a of

35 Sztuka skutecznego prowadzenia mediacji, red. A. Binsztok, Wrocław 2012, pp. 82-91.

36 It is also worth mentioning that this role is clearly evidenced by the characteristics of family disputes contained in the explanatory memorandum to Recommendation No. R(98)1 of the Committee of Ministers of the Council of Europe to Member States on Family Mediation adopted by the Committee of Ministers of 21 January 1998. This regulation is discussed in more detail in: E. Gmurzyńska, R. Morek, O problemach dotyczacych rozstrzygania spraw o blędy lekarskie i o roli mediacji, „ADR. Arbitraż i Mediacja” 2011, nr 3(15), pp. 43-77.

37 In more detail: M. Żurawska, Mediacja jako metoda rozwiazywania indywidualnych i zbiorowych sporów pracy, [in:] Mediacje. Teoria..., p. 231.

38 Zob. ibidem, p. 232.

39 More on the idea of restorative justice: J. Consedine, Sprawiedliwość naprawcza: przywrócenie ładu społecznego, Warszawa 2004, passim; D. Szumiło-Kulczycka, [in:] Mediacja. Teoria, normy, praktyka, red. K. Płeszka, J. Czapska, M. Araszkiewicz, M. Pękala, Warszawa 2017, pp. 259-267.

40 More: J. Warylewski, Kierunki i szkoły w nauce prawa karnego, [in:] System Prawa Karnego, t. 1: Zagadnienia ogólne, red. A. Marek, Warszawa 2010, p. 90. 
the Code of Criminal Procedure ${ }^{41}$, and the provisions of the Regulation of the Minister of Justice of 7 May 2015 on mediation proceedings in criminal cases ${ }^{42}$ ), leads to the conclusion that they point to the exercise by the mediator of the organisational function (including by establishing contact between the parties $-\S 14$ Point 1 of the Regulation referred to above, setting the date and place of meeting with either of them, this is in a way the first stage of mediation ${ }^{43}$ ), the information function (as indicated in $\S 14$ Point 2$)^{44}$, the mediator is obliged to provide the space for holding the mediation and to adjust the pace of the discourse to the parties. The nature of the relationship between the parties of this type of dispute and the emotional entanglement (from the point of view of the injured party) emphasizes the intensity of the stabilising, catalysing and therapeutic functions. The necessity to keep the balance between the parties (in the emotional sense and in terms of means of influence) requires the mediator to enhance the exercise of the stabilization function. After agreeing upon the content of the agreement, the mediator must think of determining the legal form and the content of the settlement (as set out in $\S 14$ Point 4 of the Regulation), and - pursuant to Article 23a $\S 4$ of the Code of Criminal Procedure - the mediator prepares a report on the course of the mediation ${ }^{45}$ and presents it to the authority which referred the case to mediation ( $\S 16$ of the Regulation). In addition, pursuant to $\S 14$ Point 5 of the Regulation, the mediator's duty to verify the performance of the provisions of the settlement indicates that the mediator exercises the supervisory function.

41 The Act of 6 June 1997 - Code of Criminal Procedure (Journal of Laws, 1997, No. 89, Item 555 as amended).

42 Journal of Laws, 2015, Item 716.

43 Accordingly, pursuant to $\S 15$ of the Regulation, the mediator may decide on indirect mediation (individual sessions) if it is not possible to arrange a direct meeting of the suspect or accused with the injured party.

44 In more detail: A. Rękas, Informowanie uczestników postępowania mediacyjnego o istocie instytucji mediacji-uwagi praktyczne, „Mediator” 2004, nr 1(28), pp. 33-37.

45 It should be noted that Article 23a of the Code of Criminal Procedure governing the institution of mediation does not explicitly list the tasks to be fulfilled by the mediator (except the obligation to draw up a report $-\S 6$ of the said provision). The obligation to consider a settlement between the perpetrator and the injured party by the law-applying authority is based on the provision of Article 53 $\S 4$ of the Penal Code (Journal of Laws, 2016,. Item 1137 as amended, consolidated text): "When imposing a penalty, the court shall take into account the positive results of the mediation carried out between the injured party and the perpetrator, or a settlement concluded between them during the proceedings before the court or the prosecutor". In addition, one should also cite Article $60 \S 2$ Point 1 of the Penal Code, which provides that the result of mediation may affect the court's decision on extraordinary mitigation of punishment, as well as Article $66 \S 3$ of the Penal Code, which extends the option for the court to order a conditional discontinuance of proceedings in the event that "the injured party has been reconciled with the perpetrator, the perpetrator has redressed the damage or the injured party and the perpetrator have agreed on the method of redressing the damage". These provisions are commented in more detail by D. Wójcik, Mediacja w polskim prawie karnym i prawie nieletnich, „Mediator” 2005, nr 2(33), pp. 11-16. 
When determining the intensity of the exercise of mediator's functions for mediation in cases involving minors ${ }^{46}$, the mediation functions should have the educational nature, in line with the purpose of the regulation ${ }^{47}$. Influencing the formation of the juvenile's personality in order to prepare him or her to live in society, educating them in correct interpersonal relations, directing the parties to self-fulfilment ${ }^{48}$ affect the exercise of the assurance, educational and authority functions. Apart from the functions discussed in the previous paragraph, the legislation on mediation in disputes involving minors, contained in the Regulation of the Minister of Justice of 18 May 2001 on mediation proceedings regarding minors ${ }^{49}$ issued based on Article $3 \mathrm{a} \S 3$ of the above-mentioned Act, points to the intensity of the exercise of the organisational, procedural and stabilizing functions by the mediator ${ }^{50}$.

To conclude with, a brief mention should be made on the mediation functions in administrative disputes and in mediation proceedings before administrative courts. Admittedly, due to the principles of administrative proceedings (including the rule of law, respect of the public interest and a legitimate individual interest) the implementation of mediation principles faces certain restrictions, but the use of this form of ADR is still possible. The principle of legalism, typical for this branch of law, determines the actions taken by the mediator, while the freedom of action of the parties is limited by the need to adhere to the instructions binding the administrative authority. The legal basis for mediation in administrative matters is Chapter $5 \mathrm{a}$ of the Code of Administrative Procedure (Articles 96f-96n). The mediator's participation under Article 96k of the Code of Administrative Procedure boils down to "running the mediation, seeking an amicable settlement of the dispute, including by supporting

46 Governed by the Act of 26 October 1982 on the procedure in cases involving minors (Journal of Laws, 2016, Item 1654, consolidated text).

47 More: M. Grudziecka, J. Książek, Mediacja w sprawach karnych i z nieletnim sprawcą czynów karalnych, „Mediator” 2010, nr 2(53), pp. 21-30.

48 In more detail: P. Kujan, Mediator - obrońca rzetelnej procedury pojednania czy wspótczesny animator wychowania?, „Mediator” 2010, nr 2, pp. 4-11.

49 Journal of Laws, 2001, No. 56, Item 591 as amended, hereinafter: the Regulation.

50 The mediator's duties listed in the Regulation include: 1) to read the information contained in the files of the case, 2) to establish contacts with the participants and take from them the consent to participate in the proceedings, 3 ) to hold individual meetings with the participants of to inform them on the nature and principles of mediation proceedings and the roles and rights of participants, 4) to hold a mediation meeting with all the participants, 5) assistance in formulating the content of the settlement between the participants and verification of the performance of resulting obligations, 6) to develop a report for the family court on the course and results of the mediation proceedings ( $\$ 14$ of the Regulation). Moreover, as in the previously discussed Regulation on mediation in criminal matters, where a direct meeting of the participants is not possible, "the mediator may carry out the mediation indirectly by providing participants with information, proposals and positions taken by each of them, unless the reasons of educational influence on the juvenile prevent this" ( $§ 15$ of the Regulation). Once the mediation is completed, the mediator's responsibility is to draw up a report on its course and to submit it to the family court (§ 17). 
the mediation participants in formulating settlement proposals" ${ }^{51}$. Thus, the content of that provision suggests higher intensity of the informative, organizational and assurance functions, while taking into account the possible hierarchical relationship between the parties (especially when one of them is a public administration body) the stabilising function. Due to the written nature of administrative proceedings and the principle of legalism, it is necessary to exercise the informative (expert) function related to clarifying the legal status of the case to the parties to the dispute.

Pointing to the exercise of mediation functions by a judge or court referendary in the judicial administrative proceedings, which, as results from the content of Article $115 \S 1$ of the Act of 30 August 2002 - Law on proceedings before administrative courts $^{52}$ consist in direct confrontation of positions of the parties, verification of their state of knowledge about law and joint seeking by the parties for a satisfactory and lawful agreement ${ }^{53}$, it should be noted that the main task of the entities exercising the function is to explain, during communication moderation, whether a breach of law occurred during the previous administrative proceedings, extent of the breach, what the effects may be and what actions should be taken to remedy this breach ${ }^{54}$. Therefore, the judge/court referendary is obliged ${ }^{55}$ (Article $115 \S 1$ and Article 117 $\S 1$ of the Law on proceedings before administrative courts) to instruct the parties on the factual and legal circumstances of the case, which will allow them to choose a specific way of settling the case ${ }^{56}$, and check whether the content of arrangements made during the mediation process will result in violation of the law or not ${ }^{57}$. Thus

51 In addition, it should be pointed out the following actions directly under the provisions of the Code of Administrative Procedure: the obligation to read through the case files (Article 96i) and to draw up a report on the mediation (Article 96m). It is worth noting the position, proposed in the literature, that the legal regulation of administrative proceedings should be applied to ensure that the conflict of interest be resolved in such a way so as not to prevent a participant from becoming the object of the government activity. Where divergent interests of the parties to the proceedings arise, the risk of blocking the decision-making process due to unresolved conflicts or reaching an unsatisfactory resolution will increase. In more detail: A. Skóra, Idea mediacji w polskim postępowaniu administracyjnym, „Mediator” 2004, nr 2(29), pp. 53-54.

52 Journal of Laws, 2017, Item 1369, consolidated text.

53 In more detail: R. Hauser, U progu reformy sądownictwa administracyjnego, „Państwo i Prawo" 2002, z. 11, p. 35.

${ }_{54}$ More: A. Drelichowska, Model mediacji w postępowaniu sądowoadministracyjnym, „ADR. Arbitraż i Mediacja” 2012, nr 2, pp. 25-40.

${ }^{55}$ Cf. A. Miruć, Mediator w postępowaniu przed sądami administracyjnymi, [in:] Arbitraż i mediacja. Praktyczne aspekty stosowania przepisów. Materiały z Konferencji Naukowej Iwonicz-Zdrój 18-20 października 2007, Rzeszów 2007, p. 195.

56 W. Ryms, Postępowanie mediacyjne, [in:] Prawo o postępowaniu przed sadami administracyjnymi (zagadnienia wybrane). Materiały na konferencję sędziów NSA, Warszawa 2003, pp. 45-46.

57 J. Kubasik, Mediacja w postępowaniu sądowoadministracyjnym jako alternatywny sposób rozwiązywania sporów z udziałem organów administracji, [in:] Mediacje w prawie, red. J. Czapska, M. Szeląg-Dylewski, Kraków 2015, p. 194. 
the information function becomes more intense, which due to the judge's and referendary's legal expertise, takes the form of expert function.

\section{CONCLUSIONS}

To sum up, one should emphasize the interdisciplinary role of the mediator as a moderator of social relations. This multifaceted character is indicated by the variety of mediation functions performed by the mediator during mediation and aimed at achieving mediation goals. The list of mediation functions presented herein is not closed, but its universality allows us to discuss a number of issues related to the performance of a professional role, including legal liability or conflict between the roles of a mediator and another professional role ${ }^{58}$. Mediation is a process characterised by dynamic interaction between the parties, so the selection and intensity of the functions depends on the definition of the situation including: dispute assessment (identification of interests and needs), interaction dynamics, type and specificity of the dispute, mediator's knowledge and skills of the mediator in the area of strategy and mediation techniques, level of emotions in the interaction between the parties, the cultural differences between the parties (including the differences in internalized social norms).

One of the determinants that affect frequency of the functions is the legal regulation of mediation. Linguistic analysis of the content of applicable legal provisions shows that in civil disputes, the mediation functions of a procedural (organisational) nature become more intensive. Due to the professional nature of the parties, business disputes emphasize the intensity of the information, advisory and expert functions, labour disputes point also to the stabilising and assurance functions, while disputes in family matters - the psychological functions (identification, catalysing, stabilisation functions). Disputes in the field of criminal law, wherein mediation reflects the idea of restorative justice, are characterised by the intensity of the stabilization and catalytic functions, as well as the supervisory function, while disputes with the participation of juvenile offenders - by the intensity of assurance and educational functions. The last group of disputes discussed herein, namely those from the sphere of administrative law, is characterised by informative (consultative, educational) functions, which are of expert character since mediation functions are entrusted also to administrative bodies or their employees (or a judge or court referendary).

58 A detailed discussion of the mediator's liability and the conflict of the roles of mediator and lawyer in the context of mediation functions is in: M. Myślińska, Mediator w polskim porzadku..., pp. 153-261, 331-341. 


\section{REFERENCES}

Consedine J., Sprawiedliwość naprawcza: przywrócenie ładu społecznego, Warszawa 2004.

Cybulko A., Siedlecka-Andrychowicz A., Mediator: role, umiejętności, osobowość, [in:] Mediacje. Teoria i praktyka, red. E. Gmurzyńska, R. Morek, Warszawa 2009.

Drelichowska A., Model mediacji w postępowaniu sądowoadministracyjnym, ,ADR. Arbitraż i Mediacja” 2012, nr 2.

Gmurzyńska E., Morek R., O problemach dotyczacych rozstrzygania spraw o błędy lekarskie i o roli mediacji, „ADR. Arbitraż i Mediacja” 2011, nr 3(15).

Green Paper on alternative dispute resolution in civil and commercial law of 10 April 2002, $\operatorname{COM}(2002) 196$.

Grudziecka M., Książek J., Mediacja w sprawach karnych i z nieletnim sprawca czynów karalnych, „Mediator” 2010, nr 2(53).

Hauser R., U progu reformy sądownictwa administracyjnego, „Państwo i Prawo” 2002, z. 11.

Kaczmarek P., Dwa ujęcia proceduralizacji prawa, [in:] Z zagadnień teorii i filozofii prawa. W poszukiwaniu podstaw prawa, red. A. Sulikowski, „Acta Universitatis Wratislaviensis” 2006, nr 2878.

Kmieciak Z., Mediacja w polskim prawie administracyjnym, [in:] Mediacja w prawie administracyjnym, red. H. Machińska, Warszawa 2007.

Korybski A., Alternatywne rozwiązywanie sporów w USA. Studium teoretycznoprawne, Lublin 1993.

Kubasik J., Mediacja w postęowaniu sądowoadministracyjnym jako alternatywny sposób rozwiazywania sporów z udziałem organów administracji, [in:] Mediacje w prawie, red. J. Czapska, M. Szeląg-Dylewski, Kraków 2015.

Kujan P., Mediator - obrońca rzetelnej procedury pojednania czy wspótczesny animator wychowania?, „Mediator” 2010, nr 2.

Miruć A., Mediator w postępowaniu przed sądami administracyjnymi, [in:] Arbitraż i mediacja. Praktyczne aspekty stosowania przepisów. Materiały z Konferencji Naukowej Iwonicz-Zdrój 18-20 października 2007, Rzeszów 2007.

Moore Ch., Mediacje. Praktyczne strategie rozwiązywania konfliktów, Warszawa 2009.

Morawski L., Główne problemy wspótczesnej filozofii prawa. Prawo w toku przemian, Warszawa 2003.

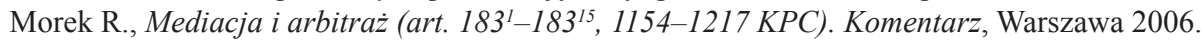

Myślińska M., Mediator w polskim porządku prawnym, Warszawa 2018.

Myślińska M., The Processes of Application of Law and the Decision Making in Mediation Process, „Studia Iuridica Lublinensia” 2015, nr 2, DOI: http://dx.doi.org/10.17951/sil.2015.24.2.115.

Nordhelle G., Mediacja. Sztuka rozwiązywania konfliktów, Gdańsk 2010.

Oniszczuk J., Konstytucja Rzeczypospolitej Polskiej w orzecznictwie Trybunału Konstytucyjnego, Kraków 2000.

Rękas A., Informowanie uczestników postępowania mediacyjnego o istocie instytucji mediacji-uwagi praktyczne, „Mediator” 2004, nr 1(28).

Ryms W., Postępowanie mediacyjne, [in:] Prawo o postępowaniu przed sądami administracyjnymi (zagadnienia wybrane). Materiaty na konferencję sędziów NSA, Warszawa 2003.

Skóra A., Idea mediacji w polskim postępowaniu administracyjnym, „Mediator” 2004, nr 2(29).

Skrzypczak G., Prawnik a sposoby rozwiązywania sporów. Prawnik wobec sytuacji konfliktowych, „Monitor Prawniczy” 2004, nr 4.

Sztuka skutecznego prowadzenia mediacji, red. A. Binsztok, Wrocław 2012.

Szumiło-Kulczycka D., [in:] Mediacja. Teoria, normy, praktyka, red. K. Płeszka, J. Czapska, M. Araszkiewicz, M. Pękala, Warszawa 2017.

Tabernacka M., Negocjacje i mediacje w sferze publicznej, Warszawa 2009.

The Act of 14 June 1960 - Code of Administrative Procedure (Journal of Laws, 2017, Item 1257, consolidated text). 
The Act of 17 November 1964 - Code of Civil Procedure (Journal of Laws, 2018, Item 155, consolidated text).

The Act of 26 October 1982 on the procedure in cases involving minors (Journal of Laws, 2016, Item 1654, consolidated text).

The Act of 5 June 1997 - Code of Criminal Procedure (Journal of Laws, 1997, No. 89, Item 555 as amended).

The Act of 6 June 1997 - Penal Code (Journal of Laws, 2016, Item 1137 as amended, consolidated text).

The Act of 30 August 2002 - Law on proceedings before administrative courts (Journal of Laws, 2017, Item 1369, consolidated text).

The Judgement of the Polish Constitutional Tribunal of 13 March 1996, K 11/95, OTK 1996, No. 2 , Item 9.

The Regulation of the Minister of Justice of 18 May 2001 on mediation proceedings regarding minors (Journal of Laws, 2001, No. 56, Item 591 as amended).

The Regulation of the Minister of Justice of 7 May 2015 on mediation proceedings in criminal cases (Journal of Laws, 2015, Item 716).

Warylewski J., Kierunki i szkoły w nauce prawa karnego, [in:] System Prawa Karnego, t. 1: Zagadnienia ogólne, red. A. Marek, Warszawa 2010.

Waszkiewicz P., Zasady mediacji, [in:] Mediacje. Teoria i praktyka, red. E. Gmurzyńska, R. Morek, Warszawa 2009.

Wójcik D., Mediacja w polskim prawie karnym i prawie nieletnich, „Mediator” 2005, nr 2(33).

Zienkiewicz A., Mediacja jako forma wymiaru sprawiedliwości, „ADR. Arbitraż i Mediacja” 2013, nr 4(24).

Zienkiewicz A., Specyfika dyskursu integracyjnego, [in:] J. Bralczyk, Wymowa prawnicza, Warszawa 2014.

Zienkiewicz A., Studium mediacji. Od teorii ku praktyce, Warszawa 2007.

Żurawska M., Mediacja jako metoda rozwiązywania indywidualnych i zbiorowych sporów pracy, [in:] Mediacje. Teoria i praktyka, red. E. Gmurzyńska, R. Morek, Warszawa 2009.

\section{STRESZCZENIE}

Przedmiotem rozważań niniejszego artykułu jest analiza aktywności podejmowanej w trakcie mediacji w kontekście specyfiki procesu decyzyjnego mediacji oraz uwarunkowań normatywnych stosunku prawnego i sporów rozwiązywanych za pomocą tej formy ADR. W celu realizacji zamierzenia treść pracy będzie zawierać katalog funkcji pełnionych przez mediatora w trakcie mediacji jako „środowiska realizowania roli” (który ze względu na dynamikę interakcji w ramach rokowań nie posiada zamkniętego charakteru). Ich charakter oraz treść przesądzają o charakterze roli społecznej i zawodowej mediatorów w polskim porządku prawnym; pozwalają również w sposób szczegółowy zobrazować kluczowe zagadnienia dla rozważań nad rolą zawodową, w tym takie, jak np. odpowiedzialność prawna czy konflikt ról. Funkcje mediacyjne ulegają zróżnicowaniu w zakresie częstotliwości ich realizacji w zależności m.in. od strategii prowadzenia mediacji, specyfiki sporu oraz regulacji prawnej mediacji. Omówienie ostatniego ze wskazanych czynników różnicujących (tj. oddziaływania prawa powszechnie obowiązującego) znajdzie odzwierciedlenie w treści pracy.

Słowa kluczowe: mediacja; mediator; funkcja mediacyjna; proces decyzyjny mediacji 